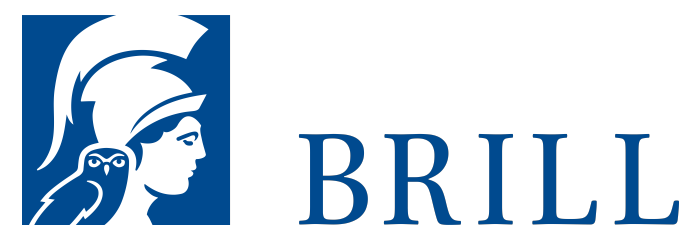

\title{
Harmonie und Synthese
}

Die russische Moderne zwischen universellem Anspruch und nationaler kultureller Identität

Author: Isabel Wünsche

Isabel Wünsche geht in ihrem Buch der Frage der Teilhabe Russlands am Projekt der europäischen Moderne nach, wobei sie sich insbesondere mit dem Wechselverhältnis zwischen universellem Anspruch und nationalen kulturellen Werten in Wissenschaft, Geistesgeschichte und Kunst beschäftigt. Mit dem Sieg über Napoleon war Russland nicht nur geographisch, sondern auch politisch und militärisch zu einer der führenden europäischen Großmächte der Moderne aufgestiegen. Die Frage, ob Russland auch in sozialer und kultureller Hinsicht zu Europa gehöre, wurde von Slawophilen und Westlern jedoch höchst unterschiedlich beantwortet; sie bildete eine der brennendsten Fragen der russischen Geistesgeschichte des 19. und frühen 2o. Jahrhunderts.

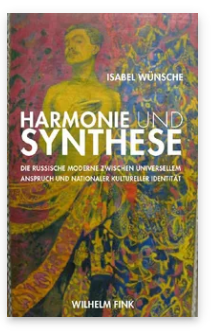

Pages: 119 Seiten

Language:

German

Subjects: Slavic,

Literature and

Cultural Studies

Publisher: Brill |

Fink

E-Book (PDF)

Released online:

$13 \mathrm{Jan} 2 \mathrm{O} 2 \mathrm{O}$

ISBN: 978-3-

8467-4686-8

List price

USD $\$ 36.00$

Paperback

Publication date:

o8 Oct 2008

ISBN: 978-3-

7705-4686-2

List price

USD $\$$ \$36.oo 
For more information see brill.com

Order information: Order online at brill.com +44330 333 0049 | customerservices@brill.com Submission information: brill.com/authors

Titles published by Brill | Fink, Brill | mentis or Brill | Schöningh: +49(o)715413279216| brill@brocom.de 